\title{
A rare erythropoietin secreting adrenal adenoma
}

\author{
J Healy ${ }^{1}$, N Abas ${ }^{1}$, C Williams ${ }^{2}$, S Evans ${ }^{2}$, H A lllif ${ }^{3}$, M Stechman ${ }^{3}$ \& A Wilton ${ }^{1}$ \\ ${ }^{1}$ Departments of Endocrinology and ${ }^{2}$ Haematology, Ysbyty Gwynedd, Bangor, UK \& \\ ${ }^{3}$ Departments of Endocrine Surgery, University Hospital of Wales, Cardiff, UK
}

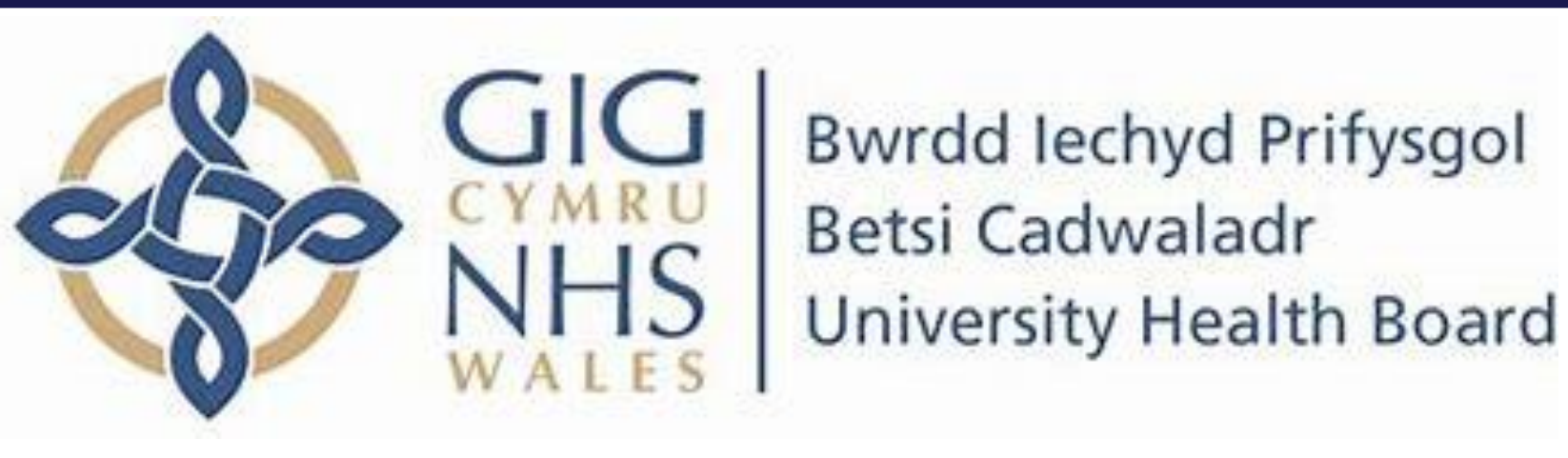

Adrenal adenomas, carcinomas and phaeochromocytomas are commonly listed as tumours that secrete erythropoietin. A literature search identified numerous cases of polycythaemia associated with adrenal adenomas secreting cortisol and testosterone. A few case reports also suggested additional erythropoietin secretion in such adenomas. We failed to identify a single case solely secreting erythropoietin.

\section{Case History}

41 year old female presented to the haematologists with the coincidental finding of polycythemia at investigation of dyspepsia : haemoglobin 198 $\mathrm{g} / \mathrm{L}$, white blood cell count $8 \times 10^{9} / \mathrm{L}$, platelets $236 \times 10^{9} / \mathrm{L}$, haematocrit $0.57 \mathrm{~L} / \mathrm{L}$ and red blood cell count $6.16 \times 10^{12} / \mathrm{L}$. Six years earlier haemoglobin had been $151 \mathrm{~g} / \mathrm{L}$, white blood cell count $7.7 \times 10^{9} / \mathrm{L}$, platelets $297 \times 10^{9} / \mathrm{L}$, haematocrit $0.4 \mathrm{~L} / \mathrm{L}$ and red blood cell count $4.53 \times$ $10^{12} / \mathrm{L}$. She was a non-smoker taking no medications. There was no history of cardiovascular or respiratory disease.

Investigations: Exon 12 of the JAK2 gene and Exon 9 of the CALR gene analyses were normal. Erythropoietin $15 \mathrm{mU} / \mathrm{ml}$ (5-25) was inappropriately normal for the prevailing haemoglobin level.

Ultrasound of kidneys confirmed them to be normal but a $6.7 \mathrm{~cm}$ rounded mass with internal calcification was present between the liver and the right kidney (Figure 1).

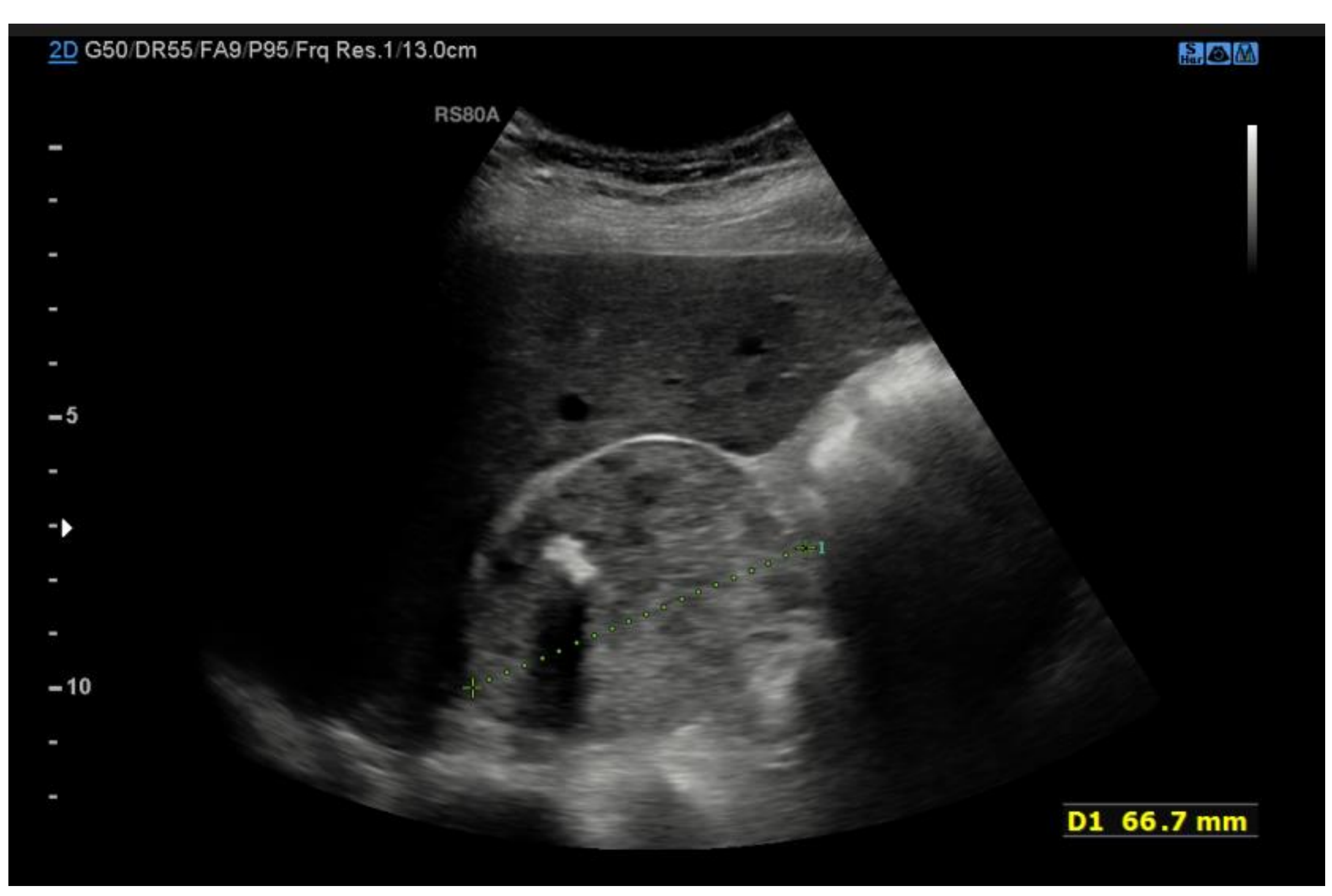

Figure 1

CT imaging pre-contrast confirmed the lesion to be a $5.8 \times 5.7 \times 5.2 \mathrm{~cm}$ adrenal mass with a focus of calcification. Post-contrast there was peripheral heterogeneous enhancement with a large central area of necrosis (fig 2). Fat planes with adjacent organs were well maintained.

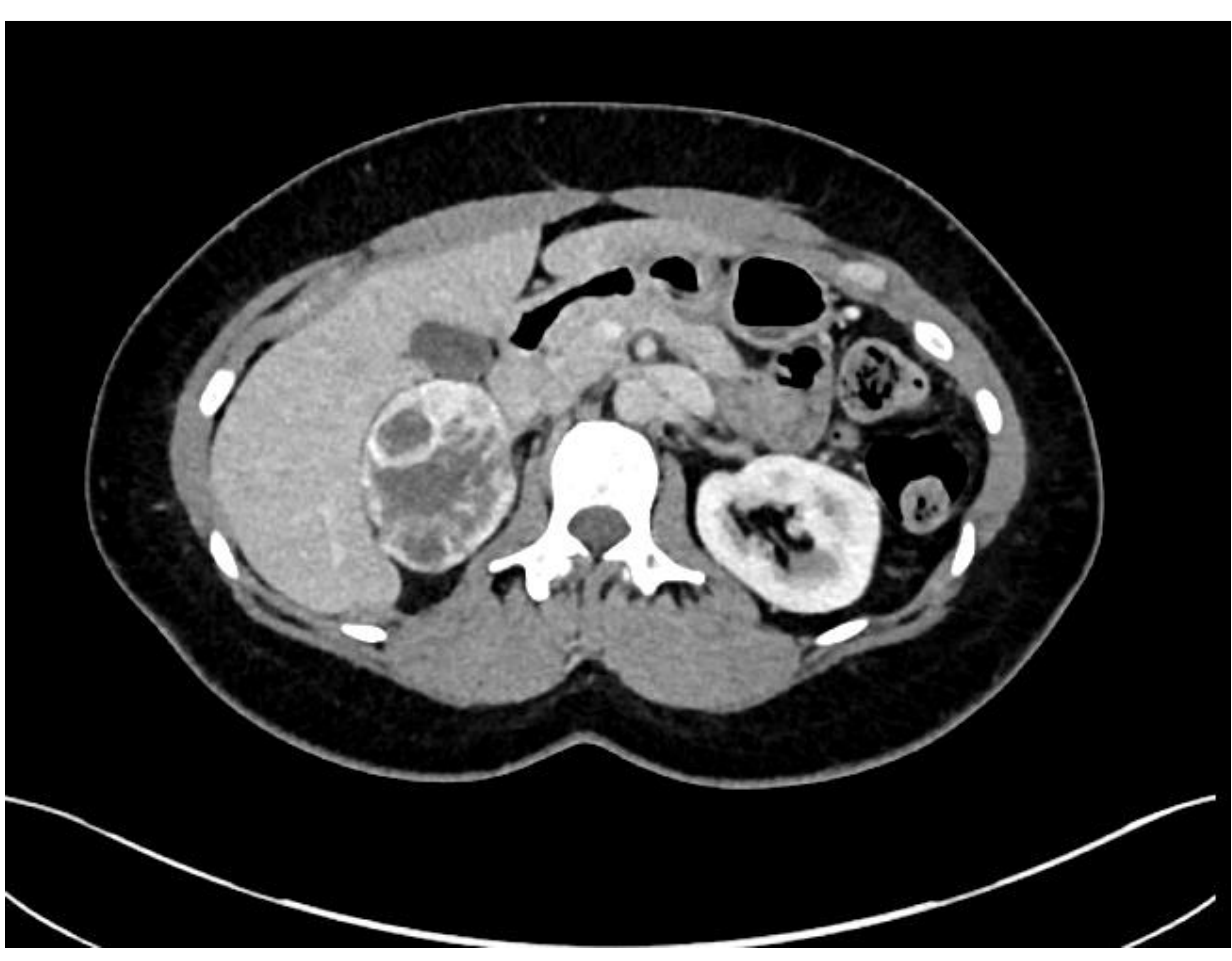

Figure 2

Referral was made to endocrinology where regular menses and normotension were confirmed. Clinically there was no evidence of hirsutism or Cushing's syndrome.

Endocrine Investigations
\begin{tabular}{|c|c|}
\hline ACTH & $14 \mathrm{ng} / \mathrm{L}(0900 \mathrm{~h}) ; 6.3 \mathrm{ng} / \mathrm{L}(1500 \mathrm{~h})$ \\
\hline Cortisol & $241 \mathrm{nmol} / \mathrm{L}(0900 \mathrm{~h}) ; 88 \mathrm{nmol} / \mathrm{L}(1500 \mathrm{~h})$ \\
\hline Plasma renin activity & $0.5 \mathrm{nmol} / \mathrm{L} / \mathrm{hr}$ \\
\hline Aldosterone & $56 \mathrm{pmol} / \mathrm{L}$ \\
\hline Plasma metadrenaline & $209.3 \mathrm{pmol} / \mathrm{L}(<510)$ \\
\hline Normetadrenaline & $377.8 \mathrm{pmol} / \mathrm{L}(<1180)$ \\
\hline 3 Methoxytyramine & $<75.0 \mathrm{pmol} / \mathrm{L}(<180)$ \\
\hline Plasma noradrenaline & $1.1 \mathrm{nmol} / \mathrm{L}(<5.0)$ \\
\hline Plasma adrenaline & $0.2 \mathrm{nmol} / \mathrm{L}(<0.8)$ \\
\hline 24 hour urinary metadrenalines $x 3$ & Normal \\
\hline
\end{tabular}

MIBG 123 whole body scan found no evidence of pathological uptake. Referral was made for right laparoscopic adrenalectomy.

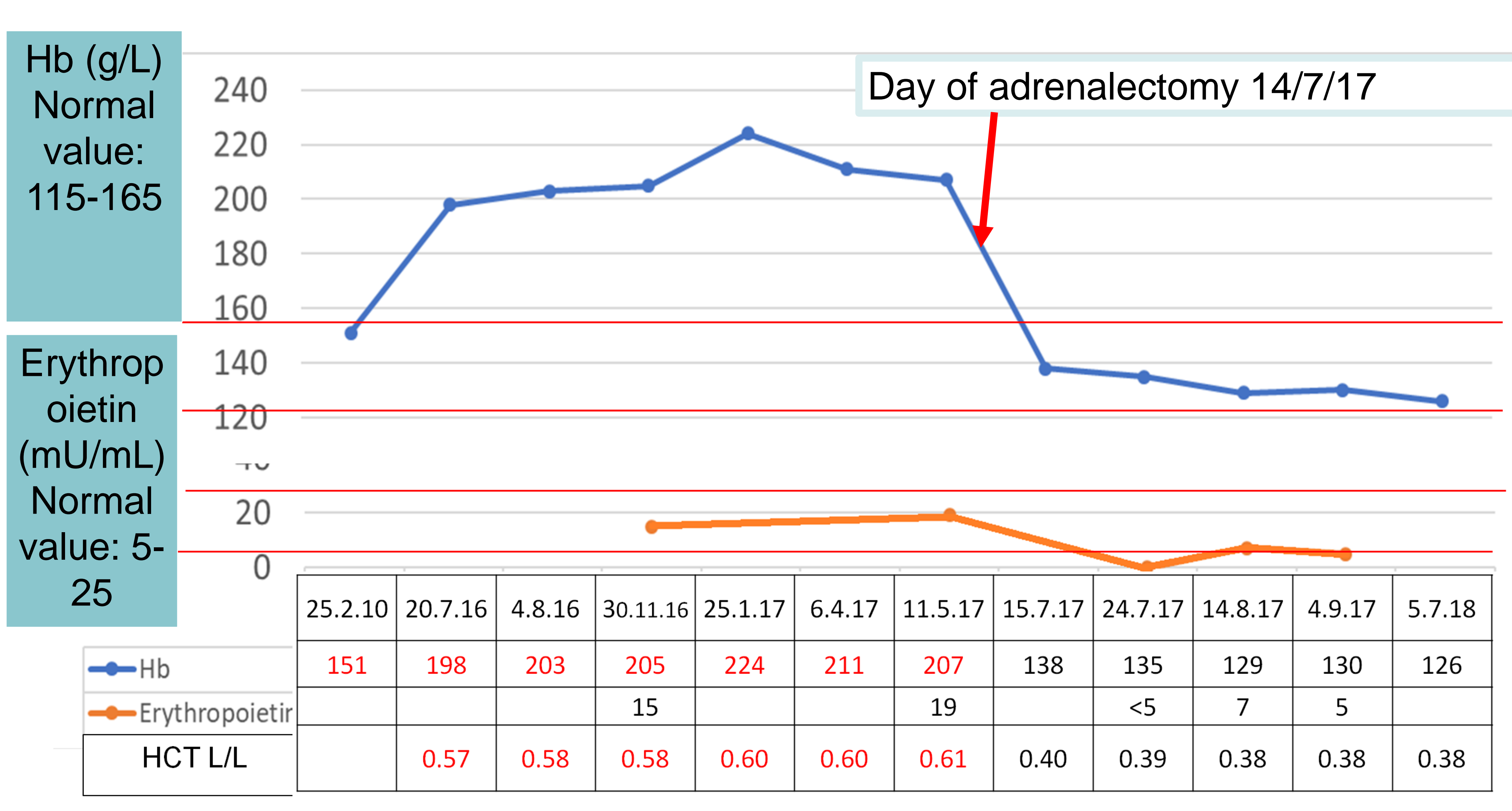

Figure 3

Post uncomplicated adrenalectomy, there was a fall in erythropoietin, haemoglobin and red blood cell count initially to sub-normal levels with rapid normalisation which has persisted (figure 3 ).

Microscopic examination of the adrenal lesion showed extensive central infarction focal ossification. The residual lesion subcapsularly was composed predominantly of spindly cells having limited cytoplasm and a population of plump cells containing large numbers of hyaline bodies. Occasional cells showed intranuclear inclusions and contained brown pigment. Mitotic activity was $0 / 10 \mathrm{hpf}$. CD34and CD31 highlight very prominent "capillary type" vascularity between the tumour cells.

Immunohistochemistry showed the lesional cells expressed vimentin but were negative for chromogranin, synaptophysin, Melan A, inhibin, pankeratin, S100 protein, GFAP, CD10 and HHV-8. Occasional cells expressed CD56. A few small sized cells showed granular positivity for Melan A scattered amongst the cells containing hyaline globules.

Based on these findings the lesion was thought to be an unusual adrenocortical adenoma.

\section{Conclusion}

We describe a case of an adrenal adenoma causing severe polycythaemia by sole secretion of erythropoietin. We believe this to be the first such description. 